\title{
EFEKTIVITAS PASAL 1 \\ PERATURAN DIREKTUR JENDRAL PAJAK NOMOR PER-18/PJ/2017
}

\author{
M Riza Aufa Rahman \\ Magister Kenotariatan Program Pascasarjana Universitas Islam Malang \\ Jl. Mayjen Haryono No. 193 Malang \\ Email: muhammadriza23@gmail.com
}

\begin{abstract}
Abstrak
Tahap Penelitian atau yang penulis biasa sebut dengan validasi SSP (Surat Setoran Pajak) merupakan tahap final dimana seorang wajib pajak telah melakukan kewajibannya dalam penyetoran pajak, dan dalam proses validasi itu sendiri tidak semua akan diterima oleh kantor pajak setempat karena masih akan dilakukan penelitian baik penelitian serara formil maupun materiil. Untuk mekanismenya validasi telah ditetapkan dalam Per18/Pj/2017 Tentang Cara Penelitian Bukti Pemenuhan Kewajiban Penyetoran Pajak Penghasilan Atas Penghasilan Dari Pengalihan Hak Atas Tanah Dan/Atau Bangunan, Dan Perjanjian Pengikatan Jual Beli Atas Tanah Dan/Atau Bangunan Beserta Perubahannya. Efektifitas pasal 1 Peraturan Direktur Jendral Pajak Nomor Per-18/Pj/2017 di Kantor Pajak Pratama Kota Malang telah sesuai akan tetapi untuk pasal 1 ayat 2 masih belum dan untuk pengikatan jual beli, dan mengenai cara pembuktian bahwa wajib pajak telah memenuhi kewajiban penyetoran adalah dengan cara validasi ataupun telah di teliti
\end{abstract}

Kata Kunci: kewajiban, penyetoran, pemenuhan, pajak, validasi

\section{Abstract}

The Research Phase or what the author commonly refers to as SSP validation (Tax Payment Deposit) is the final stage in which a taxpayer has carried out his obligations in tax payments, and in the process of validation itself not all will be accepted by the local tax office because there will still be done a research both formal and material. For the mechanism of validation, it has been stipulated in Per-18 / Pj / 2017 Regarding the Method of Research of Evidence of Fulfillment of Obligation of Income Tax on Income from Transfer of Land and / or Building Rights, and Agreement on Binding of Sale and Purchase of Land and / or Buildings and Amendments. The effectiveness of article 1 of the Regulation of the Director General of Tax Number Per-18 / Pj / 2017 in the Pratama Tax Office Malang is appropriate but for article 1 paragraph 2 it is still not yet for the 
binding of buying and selling, and regarding the means of proving that the taxpayer has fulfilled the payment obligation is by validation or thoroughly Keywords: oblilgation, deposit, fulfillment, tax, validation

\section{PENDAHULUAN}

Negara Kesatuan Republik Indonesia (NKRI) adalah negara hukum yang berdasarkan Pancasila dan Undang-Undang Dasar (UUD) Negara Republik Indonesia tahun 1945 dengan tujuan yakni mewujudkan tata kehidupan bangsa yang aman, tertib, sejahtera, dan berkeadilan, dan negara bisa di katakan negara yang sejahtera bisa di lihat dari keberhasilan suatu negara dalam mengatur sektor perekonomian.

Salah satu tolak ukur dari keberhasilan ekonomi suatu Negara dapat dilihat dari angka pertumbuhan ekonomi di negara tersebut. Peran pemerintah sebagai stabilator perekonomian dapat dijalankan dengan mengeluarkan kebijakan kebijakan untuk mengurangi kesenjangan dalam perekonomian.

Pajak merupakan salah satu sumber utama dana untuk pembangunan karena hampir sebagian besar sumber penerimaan dalam Anggaran Pendapatan dan Belanja Negara (APBN) berasal dari pajak. Pajak telah menjadi tulang punggung penggerak roda pembangunan yang sangat dominan. Tidak dapat dipungkiri lagi bahwa Wajib Pajak telah menjadi kontributor pembangunan demi eksistensi negara.

Tercapainya tujuan pembangunan bangsa ini tidak terlepas dari sumber dana yang membiayai setiap program pemerintah dalam menjalankan roda pemerintahan. Diyakini hingga sekarang bahwa sumber dana negara yang terbesar bersumber dari sektor perpajakan, bahkan dapat dikatakan bahwa tanpa pajak negara bisa lumpuh/negara tidak bisa beraktivitas, sehingga pemungutan pajak berfungsi essensial, terpenting dan harus dilaksanakan oleh negara.

Dalam memahami mengapa seseorang harus membayar pajak untuk membiayai pembangunan yang terus dilaksanakan, maka perlu dipahami terlebih dahulu tentang pengertian pajak itu sendiri. ${ }^{1}$ Pajak adalah iuran rakyat kepada kas negara berdasarkan Undang-Undang (yang dapat dipaksakan) dengan tidak mendapat jasa timbal balik (kontra prestasi) yang langsung dapat ditujukan, dan yang digunakan untuk membayar pengeluaran umum. ${ }^{2}$

Dalam PP No.34 tahun 2016 Tentang Pajak Penghasilan Atas Penghasilan Dari Pengalihan Hak Atas Tanah Dan/Atau Bangunan, Dan

${ }^{1}$ Wirawan B.Ilyas dan Richard Burton, Hukum Pajak: Teori, Analisis, dan Perkembangan, Edisi Keenam, (Jakarta: Selemba Empat, 2013). hal. 7

${ }^{2}$ Mardiasmo, Perpajakan (edisi revisi), (Yogyakarta: Andi Offset, 2005). hal. 1 
Perjanjian Pengikatan Jual Beli Atas Tanah Dan/Atau Bangunan Beserta Perubahannya, disana di jelaskan bahwa kewajiban untuk membayar pajak penghasilan sebesar 2,5\% dari nilai transaksi sebagai ketentuan dari pasal 2 ayat (1) PP No.34 tahun 2016. Akan tetapi ketika pajak tersebut telah di bayar sesuai dengan peraturan yang berlaku, bukan berati kewajiban tersebut telah selesai, akan tetapi masih dibutuhkan verifikasi ataupun validasi di kantor pajak setempat.

Fungsi dari validasi pajak adalah:

1. Untuk memastikan bahwa Bukti Surat Seteroran Pajak (SSP) tersebut Asli, karena juga ada juga SSP yang palsu.

2. Untuk memastikan bahwa penghitungan telah dilakukan dengan benar.

Dalam prakteknya tidak semua validasi yang diajukan akan diterima langsung oleh kantor pajak pratama setempat, bisa jadi ada kekeliruan ataupun kekurangan mengenai jumlah yang memang harus disetor, karena validasi itu ditentukan oleh Kantor Pajak Pratama mengenai nilai menurut kewajarannya.

\section{METODE PENELITIAN}

Jenis penelitan yang diambil oleh peneliti merupakan jenis penelitian Hukum Sosiologis. Penelitian ini merupakan penelitian yang menitikberatkan perilaku inividu atau masyarakat dalam kaitannya dengan hukum. ${ }^{3}$

Sumber data yang digunakan dalam penelitian ini adalah data primer dan data sekunder. Penelitian ini bersifat deskriptif. Pemilihan metode ini dikarenakan peneliti ini ingin mempelajari masalah-masalah, faktafakta atau fenomena yang terjadi di masyarakat dan membuat gambaran terhadap situasi yang ada. Setelah data semua terkumpul maka data tersebut oleh peneliti dianalisis sedemikian rupa dengan metode kualitatif. Metode kualitatif suatu cara analisis hasil penelitian dengan terlebih dahulu menentukan data mana atau bahan hukum manayang memiliki kualitas sebagai data atau bahan hukum yang diharapkan ataudiperlukan serta relevan dengan materi penelitian, selanjutnya dilakukan analisisterhadap data-data atau bahan-bahan hukum yang berkualitas tersebut, ${ }^{4}$ dan diambil kesimpulan.

2015). hal. 88

${ }^{3}$ Suratman dan Philips Dillah, Metode Penelitian Hukum, (Bandung: Alfabeta,

${ }^{4}$ Burhan Bungin, Analisa Data Penelitian Kualitatif, Pemahaman Filosofis dan Metodologis Kearah Penguasaan Model Aplikasi, (Jakarta: PT. Raja Grafindo Persada, 2003), hal. 53. 


\section{PEMBAHASAN}

Fungsi pajak ada dua yaitu, fungsi budgetair (sumber keuangan negara) dan fungsi regulerend (mengatur). ${ }^{5}$

1.Fungsi Budgetair (sumber keuangan negara)

Pajak mempunyai fungsi budgetair artinya pajak merupakanalah satu sumber penerimaan pemerintah untuk membiayaiengeluaran baik rutin maupun pembangunan, sebagai sumbergan negara. Upaya tersebut ditempuh dengan cara ekstensifikasi maupun intensifikasi pemungutan pajak melalui penyempurnaan peraturan berbagai jenis pajak seperti Pajak Penghasilan, Pajak Pertambahan Nilai, dan Pajak Penjualanatas Barang Mewah, Pajak Bumi dan Bangunan, dan

2. Fungsi Regulerend (mengatur)

Pajak mempunyai fungsi mengatur artinya pajak sebagai alat untuk mengatur atau melaksanakan kebijakan pemerintah dalam bidang sosial dan ekonomi, dan mencapai tujuan-tujuan tertentu di luar bidang keuangan.

Berdasarkan penjelasan fungsi pajak, dapat disimpulkan bahwa pajak berfungsi untuk membiayai pengeluaran rutin maupun pembangunan dan untuk mengatur atau melaksanakan kebijakan pemerintah.

Secara garis besarnya pajak di Indonesia di bagi 2 (dua) yakni:

1. Pajak Negara/Pusat, yaitu pajak yang di pungut oleh pemerintah pusat, penyelenggaraannya dilakukan oleh Direktorat Jenderal Pajak, digunakan untuk pembiayaan rumah tangga negara umumnya.

2. Pajak Daerah, yaitu pajak yang dipungut oleh daerah provinsi, daerah kaupaten/kota, guna pembiayaan rumah tangga daerah masing-masing. ${ }^{6}$

Direktorat Jenderal Pajak adalah lembaga yang ditunjuk oleh UndangUndang untuk melaksanakan fungsi pelayanan, pengawasan dan penegakkan hukum terhadap masyarakat Wajib Pajak dan penyelengara pemungutan pajak negara/pusat.

Sumber penerima pajak yang dapat diperoleh oleh negara salah satunya adalah berasal dari tanah dan atau bangunan. Tanah dan bangunan memberikan keuntungan dan/atau kedudukan sosial ekonomiyang lebih baik bagi orang atau badan yang mempunyai suatu hak atasnya atau memperoleh manfaat dari padanya, dan oleh karena itu wajar apabila mereka diwajibkan memberikan sebagian dari manfaat atau kenikmatan yang diperolehnya kepada negara melalui pajak.

${ }^{5}$ Siti Resmi, Perpajakan Teori dan Kasus, (Jakarta: Salemba Empat, 2004). hal. 2

${ }^{6}$ Ida Zuraida, Penagihan Pajak, Pajak Pusat dan Pajak Daerah, (Bogor: Ghalia Indonesia, 2011). hal. 9 
Dalam setiap transaksi atas pengalihan hak atas tanah dikenal adanya dua Macam pajak yang harus dibayarkan oleh masing-masing para pihak, yaitu: ${ }^{7}$

1. Pajak Penghasilan (PPh) yang harus dibayar atas nama pihak yang mengalihkan hak atas tanah atau hak milik atas satuan rumah susun, yang diatur dalam Peraturan Pemerintah (PP) nomor 48 tahun 1994 tentang Pembayaran Pajak Penghasilan atas penghasilan dari pengalihan hak atas tanah dan atau bangunan, diubah dengan PP nomor 27 tahun 1996, diubah lagi dengan PP nomor 79 tahun 1999, terakhir diubah dengan PP nomor 71 tahun 2008, PPh terdiri dari PPh yang tidak bersifat final dan PPh yang bersifat final. Berdasarkan Pasal 1 Undang-Undang Nomor 36 Tahun 2008 tentang Perubahan Keempat atas Undang-Undang Nomor 7 Tahun 1983 tentang Pajak Penghasilan, PPh yang tidak bersifat final dikenakan terhadap subjek pajak atas penghasilan yang diterima atau diperolehnya dalam tahun pajak. Sedangkan $\mathrm{PPh}$ yang bersifat final yaitu pajak penghasilan yang dibayar, dipotong, atau dipungut atas transaksi atau penghasilan tertentu dengan menerapkan tarif tersendiri yang dihitung berdasarkan pada penghasilan brutonya, yang pemenuhannya bersifat final. ${ }^{8}$

2. Bea Perolehan Hak atas Tanah dan Bangunan (BPHTB) yang harus dibayar atas nama penerima/yang memperoleh hak atas tanah atau hak milik atas satuan rumah susun, yang diatur dalam Undang-Undang (UU) nomor 28 tahun 2009 yaitu UndangUndang tentang Pajak Daerah dan Retribusi Daerah. Khusus tentang BPHTB diatur dalam Pasal 85 sampai Pasal 93. UndangUndang ini mulai berlaku sejak tanggal 01 Januari 2010.

Pengalihan pengelolaan Bea Perolehan Hak atas Tanah dan Bangunan (BPHTB) dari Pemerintah Pusat kepada Pemerintah Daerah merupakan suatu bentuk tindak lanjut kebijakan otonomi daerah dan desentralisasi fiskal. Bentuk kebijakan tersebut dituangkan ke dalam Undang-Undang Nomor 28 Tahun 2009 tentang Pajak Daerah dan Retribusi Daerah.

Pembayaran PPh dan BPHTB merupakan salah satu syarat pendaftaran peralihan hak atas tanah tersebut, dimana dalam ketentuan Pasal 103 Peraturan Menteri Negara Agraria/Kepala Badan Pertanahan Nasional Nomor 3 Tahun 1997 tentang Ketentuan Pelaksanaan Peraturan Pemerintah

${ }^{7}$ Mustofa, Tuntunan Pembuatan Akta-Akta PPAT, (Yogyakarta: KaryaMedia, 2014 ha)l. 21

${ }^{8}$ Fauzi Malik, "Penerapan PPh Final dalam sistem self assesment ditinjau dari Asas Keadilan", Berita Pajak, nomor 1506, 2004, hal. 1 
Nomor 24 Tahun 1997 tentang Pendaftaran Tanah, disebutkan bahwa dalam pendaftaran peralihan hak atas tanah, PPAT wajib menyampaikan akta dan dokumen-dokumen yang diperlukan dalamproses pendaftaran peralihan haknya ke Kantor Badan Pertanahan Nasional setempat. Salah satu dokumen yang dimaksud adalah bukti pelunasan pembayaran Bea Perolehan Hak atas Tanah dan Bangunan (BPHTB) dan bukti pelunasan pembayaran $\mathrm{PPh}$ final atas peralihan hak atas tanah dan/atau bangunan.

Setiap kantor pajak pastilah mempunyai target yang ingin dicapai dalam penerimaan pajak dalam berbagai sektor yang ada demi menyejahterakan rakyat, karena tidak dipungkiri pajak merupakan salah satu penyumbang pendapatan terbesar dalam negara kita ini, dan dapat dikatakan negara itu maju apabila Wajib pajak telah melakukan kewajibaanya yakni membayar pajak.

Setiap tahun target tiap kantor pajak selalu berubah ubah, dan berbagai cara telah dilakukan demi meningkatkan pendapatan negara dalam bidang perpajakan dengan diluncurkannya Tax Amnesti (Pengampuan Pajak). Di kota Malang terdapat 2 kantor pajak prama yang masing-masing mewakili daerah kerjanya sendiri. Yakni Kantor Pajak Pratama Malang Selatan dan Kantor Pajak Malang Pratama Selatan.

Kantor Pajak Malang Pratama sendiri pada tahun 2016 tercatat pendapatan hingga 900 miliar, sedangkan pada tahun 2017 mencatatkan pendapatan sebesar 689 Miliar per 29 Desember 2017. Memang hasil tersebut merupakan jumlah keseluruhan pendapatan dari berbagai sektor, salah satu diantaranya adalah pendapatan pengalihan hak atas tanah.

Setiap peralihan hak atas tanah haruslah membayar pajak, baik itu pajak penjual/megalihkan dan pajak pembeli/yang menerima pengalihan, karna ketika seseorang mengalihkan tanah bangunan kepada orang lain maka satu proses yang harus dibutuhkan ketika seseorang yang menerima pengalihan tersebut haruslah terbayar kedua pajak tersebut. Apabila pajak tersebut tidak terbayar maka ketika akan melakukan pengurusan peralihan hak atas tanah dan/bangunan di Badan Pertanahan Nasional setempat, maka permohonan seseorang untuk menerima melakukan peralihan baik itu jualbeli akan tersendat, dalam arti akan ditolak oleh kantor badan pertanahan nasional setempat. Hal ini senada dengan wawancara penulis dengan Bambang Ismono selaku Seksi Pengawas dan Konsultasi I, dikatakan bahwa untuk pajak penjual atau yang biasa disebut dengan SSP ini para wajib pajak sudah taat pada aturan yang ada yakni dengan membayar pajak penghasilan dari penjualan tanah atau rumah karena ketika pajak ini tidak di bayarkan maka nanti ketika permohonan balik nama (peralihan hak) di Badan Pertanahan Nasional biasanya tidak diterima karena belum terbayarkannya pajak penjual, sehingga para wajib pajak taat aturan 
Pada dasarnya ketika seseorang tidak melakukan pembayaran pajak pengikatan jual beli tidak ditemukan sanksi yang menjeratnya, karena perjanjian pengikatan jual beli sampai saat ini tidak ditemukan haruslah di buatkan laporan kepada kantor pajak pratama setempat. Hal ini mungkin bisa menjadi penyebab kenapa pajak pengikatan jual beli tersebut tidaklah terbayarkan karena tidak bisa tedeteksi langsung oleh Kantor Pajak Pratama.

Meskipun begitu, pengikatan jual beli termasuk "peralihan yang tertunda", kenapa bisa dikatakan seperti itu, penulis berasumsi karena akta pengikatan jual beli tidak semua langsung terjadi peralihan hak, akan tetapi menunggu "ikatan" tersebut telah selesai. Karena pada prakteknya, akta pengikatan jual beli tidak bisa dijadikan acuan bahwa terjadi peralihan hak atas tanah/bangunan, karena akta tersebut di buat oleh seorang notaris ${ }^{9}$ bukan seorang PPAT. Karena setiap peralihan hak atas tanah dan/bangunan ketika akan di daftarkan di kantor badan pertanahan setempat haruslah dibuktikan dengan adanya akta yang dibuat di hadapan pejabat PPAT yang berwenang dalam wilayahnya.

Ketika seorang wajib pajak akan melakukan penyetoran pajak penghasilan atas penghasilan dari pengalihan hak atas tanah, hal yang harus dilakukan adalah menghitung jumlah pajak yang akan disetorkan. Setelah itu seorang wajib pajak akan menyetetorkan pajak kepada bank yang telah ditunjuk oleh pemerintah dengan melampirkan kode billing yang dibuat oleh notaris ataupun dibuat sendiri di kantor pajak pratama di wilayah domilisi. Ketika wajib pajak telah melakukan pembayaran, maka akan dilakukan tahap penelitian ataupun tahap validasi yang dilakukan oleh kantor pajak pratama setempat.

Bambang Ismono mengatakan untuk membuktikan wajib pajak telah memenuhi kewajibannya dengan mengajukan permohonan penelitian pajak di kantor pajak ini, dengan mengisi blanko yang telah tersedia. Setelah mengisi blanko dan pensyaratan-persyaratan telah terpenuhi, maka di ajukan kepada loket di depan. Setelah itu dalam 3 (tiga) hari kerja akan kami keluarkan apakah permohonan tersebut diterima atau di tolak. Kalau diterima maka akan di keluarkan surat hasil penelian, maka kewajiban wajib pajak telah terpenuhi dan jika ditolak maka harus di perbaiki dan jika sudah bisa di ajukan kembali. ${ }^{10}$

Tahap Penelitian merupakan tahap akhir ketika orang pribadi atau badan hukum telah melakukan pembayaran pajak pengalihan tanah/bangunan, karena tidak serta merta seseorang telah membayar pajak

\footnotetext{
${ }^{9}$ Abdul Wahid, Mariyadi, dan Sunardi, Penegakan Kode Etik Profesi Notaris (Jakarta: Nirmana Media, 2017), hal. 35.

${ }^{10}$ Wawancara dengan Bambang Ismono, Seksi Pengawas dan Konsultasi I, tanggal 14 Mei 2019
} 
tersebut telah diterima oleh negara dalam hal ini kantor pajak. Tahapan tersebut merupakan tahapan dimana pajak penghasilan yang diterima oleh orang pribadi atau badan hukum akan dicek oleh kantor pajak apakah telah sesuai dengan keadaan yang sebenarnya.

Tahap Penelitian atau yang penulis biasa sebut dengan validasi Surat Setoran Pajak (SSP) diajukan ke Kantor Pajak Pratama (KPP) yang wilayah kerjanya meliputi letak tanah/bangunan yang dialihkan, menggunakan Formulir penelitian SSP sesuai Lampiran I PER 26/PJ/2017 dan dilampiri:

1. Surat Setoran Pajak (SSP) yang sudah tertera Nomor Transaksi Penerimaan Negara dan Nomor (NTPN)

2. Transaksi Bank/Nomor Transaksi Pos/Nomor Penerimaan Potongan atau sarana administrasi lainnya yang disamakan dengan Surat Setoran Pajak;

3. Surat pernyataan pengalihan hak atas tanah dan/ atau bangunan atau perjanjian pengikatan jual beli atas tanah dan/ atau bangunan beserta perubahannya yang telah diisi secara lengkap dan dibubuhi meterai dengan menggunakan formulir sesuai Lampiran II PER 18/PJ/2017;

4. Fotokopi seluruh faktur/bukti penjuatan, bukti transfer dan/ atau fotokopi bukti penerimaan uang secara tunai yang telah ditandatangani pihak yang mengalihkan tanah dan/ atau bangunan di atas meterai;

5. Fotokopi Surat Pemberitahuan Pajak Terutang Pajak Bumi dan Bangunan (SPPT PBB) atau bukti penagihan Pajak Bumi dan Bangunan lainnya untuk tahun terakhir;

6. Fotokopi Kartu Tanda Penduduk (KTP) bagi pembeli dan penjual yang berstatus Warga Negara Indonesia (WNI);

7. Surat kuasa dan fotokopi KTP yang diberi kuasa untuk menyampaikan dan/ atau mengambil dokumen dalam hal penyampaian permohonan penelitan dikuasakan;

8. Foto Lokasi terbaru dan juga alamat lokasi (bisa dengan citra satelit dengan menunjukan koordinat)

9. Fotokopi brosur, price list, dan Perjanjian Pengikatan Jual Beli (PPJB) dalarn hal pengalihan tanah dan/atau bangunan dilakukan oleh pengembang; dan

10. Surat pernyataan tidak wajib menggunakan Nomor Pokok Wajib Pajak sebagaimana tercantum dalam Lampiran III PER 18/PJ/2017 dalam hal penyetoran Pajak Penghasilan tanpa menggunakan Nomor Pokok Wajib Pajak.

Dalam hal pengalihan hak atas tanah dan/atau bangunan dilakukan kepada Special Purpose Company atau Kontrak Investasi Kolektif dalam skema Kontrak Investasi Kolektif tertentu sebagaimana dimaksud dalam 
peraturan perundang-undangan yang mengatur tentang Pajak Penghasilan atas penghasilan dari pengalihan Real Estat dalam skema Kontrak Investasi Kolektif tertentu, permohonan penelitian sebagaimana dimaksud pada Pasal 3 atau Pasal 3A Peraturan Direktur Jenderal Pajak Nomor Per - 26/Pj/2018, juga harus dilengkapi dengan dokumen:

a. fotokopi pemberitahuan efektifnya pernyataan pendaftaran Dana Investasi Real Estat berbentuk Kontrak Investasi Kolektif yang diterbitkan dan telah dilegalisasi oleh Otoritas Jasa Keuangan;

b. keterangan dari Otoritas Jasa Keuangan bahwa Wajib Pajak yang mengalihkan Real Estat bertransaksi dengan Special Purpose Company atau Kontrak Investasi Kolektif dalam skema Kontrak Investasi Kolektif tertentu; dan

c. surat pernyataan bahwa Wajib Pajak melakukan pengalihan Real Estat kepada Special Purpose Company atau Kontrak Investasi Kolektif dalam skema Kontrak Investasi Kolektif tertentu dengan meterai.

Pada pasal 2 disebutkan bahwa tahap penelitian yang dilakukan oleh kantor pajak ada 2 macam, yakni tahap penelitian formal dan tahap penelitian meterial.

1. Tahap penelitian Formal dilakukan kantor pajak berkaitan dengan wilayah kerja, apakah lokasi tanah/bangunan tersebut masih dalam kewenangan kantor pajak setempat, hal ini bisa di cek dari kartu identitas penyetor pajak, dengan cara:

a. mengecek kelengkapan surat permohonan penelitian bukti pemenuhan kewajiban penyetoran Pajak Penghasilan; dan memastikan kesesuaian:

b. identitas Wajib Pajak dalam bukti pemenuhan kewajiban penyetoran Pajak Penghasilan dengan data di Direktorat Jenderal Pajak dan/atau fotokopi Kartu Tanda Penduduk atau Paspor;

c. jumlah Pajak Penghasilan yang telah disetor oleh Wajib Pajak dengan Pajak Penghasilan yang seharusnya terutang berdasarkan surat pernyataan sebagaimana dimaksud dalam Pasal 3 ayat (2) huruf $b$; dan

d. kode akun pajak, kode jenis setoran, dan jumlah Pajak Penghasilan yang disetor oleh Wajib Pajak, dengan data penerimaan pajak dalam Modul Penerimaan Negara.

2. Tahap Penelitian Material

a. Tempat Wajib Pajak terdaftar, dimana:

Surat Pemberitahuan Tahunan Pajak Penghasilan Wajib Pajak diadministrasikan; atau kegiatan usaha dilakukan, dalam hal Wajib Pajak merupakan Wajib Pajak yang usaha 
pokoknya melakukan pengalihan hak atas tanah dan/atau bangunan; atau

b. $\quad$ yang wilayah kerjanya meliputi tempat tinggal, untuk orang pribadi yang belum memiliki Nomor Pokok Wajib Pajak.

Apabila semua persyaratan telah terpenuhi, maka seowang wajib pajak akan mendapatkan tanda terima bukti bahwa permohonan penelitian validasi telah masuk dalam kantor pajak pratama.

1. Surat Keterangan Penelitian Formal Bukti Pemenuhan Kewajiban Penyetoran Pajak Penghasilan diterbitkan dalam jangka waktu: paling lama 3 (tiga) hari kerja dalam hal permohonan penelitian bukti pemenuhan kewajiban penyetoran Pajak Penghasilan dilakukan Wajib Pajak sebagaimana dimaksud pada Pasal 3 ayat (1), Pasal 3A ayat (1) dengan jumlah bukti pembayaran dalam daftar pembayaran pajak penghasilan paling banyak 10 buah, dan Pasal 3B; dan

2. paling lama 10 (sepuluh) hari kerja dalam hal permohonan penelitian bukti pemenuhan kewajiban penyetoran Pajak Penghasilan dilakukan Wajib Pajak sebagaimana dimaksud pada Pasal 3A ayat (1) dengan jumlah bukti pembayaran dalam daftar pembayaran pajak penghasilan lebih dari 10 buah,

Surat permohonan penelitian ini ada yang langung diterima dalam artian ada surat keputusan yang dikeluarkan oleh kantor pajak pratama setempat yang telah di tandatangani dan distempel resmi.

Apabila surat permohona tidak diterima, dalam pasal 4 per-18/PJ/2018 dijelaskan bahwa:

1. Dalam hal Surat Keterangan Penelitian Formal Bukti Pemenuhan Kewajiban Penyetoran Pajak Penghasilan tidak dapat diterbitkan, permohonan penelitian bukti pemenuhan kewajiban penyetoran Pajak Penghasilan dikembalikan kepada Wajib Pajak dengan Surat Pemberitahuan Permohonan Penelitian Tidak Lengkap dan/atau tidak sesuai dalam jangka waktu paling lama 3 (tiga) hari kerja sejak tanggal permohonan penelitian diterima.

2. Surat Pemberitahuan Permohonan Penelitian Tidak Lengkap dan/atau Tidak Sesuai sebagaimana dimaksud pada ayat (1) atas permohonan penelitian sebagaimana dimaksud dalam:

a. Pasal 3 ayat (1) dibuat sesuai dengan format tercantum dalam Lampiran V; dan

b. Pasal 3A ayat (1) dibuat sesuai dengan format tercantum dalam Lampiran VA, yang merupakan bagian tidak terpisahkan dari Peraturan Direktur Jenderal ini.

3. Wajib Pajak atau kuasanya mengambil Surat Keterangan Penelitian Formal Bukti Pemenuhan Kewajiban Penyetoran Pajak Penghasilan 
sebagaimana dimaksud pada Pasal 4 ayat (1) atau Surat Pemberitahuan Permohonan Penelitian Tidak Lengkap dan/atau Tidak Sesuai sebagaimana dimaksud pada ayat (1) di Kantor Pelayanan Pajak yang wilayah kerjanya meliputi lokasi tanah dan/atau bangunan dalam jangka waktu sebagaimana dimaksud pada Pasal 4 ayat (2) atau Pasal 4A ayat (1).

Dalam hal permohonan penelitian bukti pemenuhan kewajiban penyetoran Pajak Penghasilan dikembalikan sebagaimana dimaksud pada ayat (1), Wajib Pajak dapat menyampaikan kembali permohonan penelitian bukti pemenuhan kewajiban penyetoran Pajak Penghasilan setelah melengkapi dan/atau menyesuaikan dokumen sebagaimana dimaksud dalam Pasal 3, Pasal 3A dan/atau Pasal 3B.

\section{KESIMPULAN}

Pasal 1 ayat 1 Peraturan Direktur Jendral Pajak Nomor Per18/Pj/2017 di Kantor Pajak Pratama Kota Malang sudah efektif dalam penerapanya, Akan tetapi untuk pasal 1 ayat 2 Peraturan Direktur Jendral Pajak Nomor Per-18/Pj/2017 di Kantor Pajak Pratama Kota Malang, kurang begitu efektif, dikarenakan kurangnya sosialisasi kepada masyarakat dan kurangnya kesadaran diri masyarakat akan taat pajak.

Untuk mengetahui seseorang wajib pajak telah memenuhi kewajiban penyetoran pajak penghasilan atas penghasilan dari pengalihan hak atas tanah yang pertama dengan bukti pembayaran pajak di bank daerah atau bank yang telah bekerja sama dengan pemerintah daerah, setelah itu untuk mengetahui pembayaran tersebut telah sesuai tidaknya dengan pendapatan yang wajib peroleh miliki adalah dengan mengajian penelitian di Kantor Pajak Pratama Kota Malang, yang nantinya ketika sudah dilakukan penelitian dan hasilnya sesuai maka akan di keluarkannya surat keputusan yang mana surat keputusan tersebut akan di tandatangani dan di stempel oleh pejabat Kantor Pajak Pratama Kota Malang.

\section{DAFTAR PUSTAKA}

\section{Buku}

Abdul Wahid, Mariyadi, dan Sunardi, 2017, Penegakan Kode Etik Profesi Notaris Jakarta: Nirmana Media.

Burhan Bungin, 2003, Analisa Data Penelitian Kualitatif, Pemahaman Filosofis dan Metodologis Kearah Penguasaan Model Aplikasi, Jakarta: PT. Raja Grafindo Persada.

Mardiasmo, 2005, Ida Zuraida, 2001, Penagihan Pajak, Pajak Pusat dan Pajak Daerah, Bogor: Ghalia Indonesia. 
Perpajakan (edisi revisi), Yogyakarta: Andi Offset.

Mustofa, Tuntunan Pembuatan Akta-Akta PPAT, Yogyakarta: Karya Media.

Siti Resmi, 2014, Perpajakan Teori dan Kasus, Salemba Empat, Jakarta.

Suratman dan Philips Dillah, 2015, Metode Penelitian Hukum, Bandung: Alfabeta.

Wirawan B.Ilyas dan Richard Burton, 2013, Hukum Pajak: Teori, Analisis, dan Perkembangan, Edisi Keenam, Jakarta: Selemba Empat.

\section{Peraturan Perundang-undangan}

PP No.34 tahun 2016 Tentang Pajak Penghasilan Atas Penghasilan Dari Pengalihan Hak Atas Tanah Dan/Atau Bangunan, Dan Perjanjian Pengikatan Jual Beli Atas Tanah Dan/Atau Bangunan Beserta Perubahannya

Undang-Undang Nomor 28 Tahun 2009 tentang Pajak Daerah dan Retribusi Daerah

\section{Majalah}

Fauzi Malik, "Penerapan PPh Final dalam sistem self assesment ditinjau dari Asas Keadilan”, Berita Pajak, nomor 1506, 2004. 